\title{
Influence of Dietary Supplementation of Arginine or Glycine on the Adverse Effect in Chicks Given a Tyrosine Excess Diet
}

\author{
Masao Yanaka and Jun-ichi Okumura \\ Laboratory of Animal Nutrition, Faculty of Agriculture, \\ Nagoya University, Nagoya-shi 464
}

When chicks are given a diet containing an excessive amount of tyrosine, their growth is retarded ${ }^{1-4)}$ and they develop lesions of the feet and eyes ${ }^{4}$. These adverse effects can be overcome by an addition of dietary protein ${ }^{4}$. Some attempts have been made to alleviate growth-depressing effect of excess tyrosine in chicks by supplemental arginine ${ }^{5 \sim 7)}$. SMITH ${ }^{6}$ showed that growth depression in chicks given a basal diet containing $12 \%$ crude protein from casein supplemented with 3\% tyrosine was significantly alleviated by the addition of 0.6 to $1.5 \%$ arginine $\cdot \mathrm{HCl}$. SNETSINGER and $\mathrm{Scotr}^{8)}$ reported the ameliorative effect of supplemental arginine and/or glycine on growth depression due to dietary excess of single supplemental amino acid, i. e., lysine, histidine and phenylalanine. However, more detailed studies on the effect of arginine or glycine have not as yet been done.

As part of a study aimed at determining the factors that can alleviate the detrimental effect of excess tyrosine, we examined the effects of supplemental arginine or glycine on growth, nitrogen utilization, free amino acid concentration in plasma and excretion of some nitrogenous compounds in droppings of chicks given a $5 \%$ tyrosine diet.

\section{Experimental procedure}

Day-old Single Comb White Leghorn male chicks were housed in electrically-heated brooders. They received a commercial chick mash for 7 days. On day 8 the chicks were individually weighed after having been fasted for 2 hours and were then selected and distributed, based on their body weights, in 12 groups of five chicks each. They were then housed individually in metabolism cages ${ }^{9}$ for the measurement of feed consumption and quantitative collection of droppings. Eleven groups of five chicks each were fed their corresponding experimental diets ad libitum from day 8 to day 22 . Water was made available at all times. The remaining five chicks of the last group were killed with diethyl ether and used to determine the initial body composition.

The basal diet $(20 \%$ crude protein content) contained, in percentage by weight, isolated soybean protein, 24.93; sucrose, 20.00; aluminum silicate, 10.00; cellulose, 5.00; corn oil, 3.00; L-methionine, 0.10; choline chloride, 0.15 ; vitamin mixture ${ }^{9)}$, 0.20; mineral mixture ${ }^{10)}, 5.63$ and cornstarch, make up to 100 . The chick's requirement for methionine $^{11)}$ was just met by the supplementary level indicated. Tyrosine excess diet was prepared by adding $5.0 \%$ L-tyrosine to the basal diet at the expense of cornstarch. Arginine or glycine supplemented diets were made by adding $0.5,1.0,1.5,2.0$ and $2.5 \%$ 
of L-arginine $\cdot \mathrm{HCl}$ and $1.0,2.0,3.0$ and $4.0 \%$ of glycine, respectively, to the tyrosine excess diet at the expense of cornstarch. When the experimental diet containing L-arginine $\cdot \mathrm{HCl}$ was prepared, appropriate amounts of sodium bicarbonate were added to neutralize the hydrochloride in arginine.

The chicks were weighed and feed consumption was measured every other day. The droppings from each chick were collected into $100 \mathrm{ml} 0.1 \mathrm{~N}$ hydrochloric acid in deep, stainless steel trays beneath the metabolism cages. The acid prevented further microbial action and loss of ammonia in the droppings. Droppings collected daily during the last 4 days were air-dried at $60^{\circ} \mathrm{C}$ and used for the determinations of total nitrogen, uric acid and total creatinine. Total nitrogen was analyzed by the Kjeldahl method and uric acid was determined according to PudelKIewicz et al. ${ }^{12)}$ and total creatinine was determined spectrophotometrically by the Jaffé reaction ${ }^{13)}$.

At the end of the 14-day experimental period, blood was obtained in heparinized syringe by cardiac puncture. Plasma was separated by centrifugation and deproteinized with 5 volumes of $1 \%$ picric acid solution. The deproteinized plasma samples were frozen and kept in that state until they were analyzed for free amino acids. Before analysis equal volumes of deproteinized plasma samples from five chicks within each treatment were pooled. Amino acid was determined with the amino acid autoanalyzer, JEOL model JLC-5AH. All chicks were killed for carcass analysis, at the end of the experiment. Carcasses were treated according to the procedure described by OKUMURA and Mori ${ }^{14}$. Nitrogen retention during the experimental period was estimated by subtracting the initial values (day 8) of body composition from the final ones (day 22). Results were subjected to an analysis of variance. Comparison of treatment means was tested by Duncan's multiple range method ${ }^{15}$. More generally, the variability of each treatment mean is indicated by the standard error of mean.

\section{Results}

Table 1 gives the effect of dietary supplementation of arginine or glycine on body

Table 1. Effect of dietary supplementation of arginine or glycine on body weight gain, feed intake and gain:feed ratio in chicks given a $5 \%$ tyrosine diet (Mean \pm SEM for 5 birds)

\begin{tabular}{|c|c|c|c|}
\hline \multirow{2}{*}{ Diet } & Body weight gain & Feed intake & \multirow{2}{*}{ Gain:feed } \\
\hline & \multicolumn{2}{|c|}{$\mathrm{g} / \mathrm{bird} / 14$ days } & \\
\hline Basal (B) & $118.6 \pm 5.9^{\mathrm{a}}$ & $262.6 \pm 8.3^{\mathrm{a}}$ & $0.451 \pm 0.015^{\mathrm{a}}$ \\
\hline $\mathrm{B}+5.0 \% \mathrm{~L}-\mathrm{Tyr}(\mathrm{T})$ & $60.4 \pm 5.2^{\mathrm{b}}$ & $184.2 \pm 8.6^{\mathrm{b}}$ & $0.326 \pm 0.014^{b}$ \\
\hline $\mathrm{T}+0.5 \% \quad \mathrm{~L}-\mathrm{Arg} \cdot \mathrm{HCl}$ & $61.2 \pm 6.5^{\mathrm{b}}$ & $186.8 \pm 7.6^{b}$ & $0.327 \pm 0.028^{b}$ \\
\hline $\mathrm{T}+1.0 \% \mathrm{~L}-\mathrm{Arg} \cdot \mathrm{HCl}$ & $62.2 \pm 5.8^{\mathrm{bc}}$ & $193.4 \pm 8.7^{b}$ & $0.320 \pm 0.017^{b}$ \\
\hline $\mathrm{T}+1.5 \% \quad \mathrm{~L}-\mathrm{Arg} \cdot \mathrm{HCl}$ & $78.6 \pm 6.8^{\mathrm{bc}}$ & $228.8 \pm 10.3^{c}$ & $0.342 \pm 0.016^{\mathrm{b}}$ \\
\hline $\mathrm{T}+2.0 \% \mathrm{~L}-\mathrm{Arg} \cdot \mathrm{HCl}$ & $81.6 \pm 5.8^{\mathrm{cd}}$ & $228.0 \pm 12.0^{\mathrm{c}}$ & $0.356 \pm 0.007^{\mathrm{bc}}$ \\
\hline $\mathrm{T}+2.5 \% \mathrm{~L}-\mathrm{Arg} \cdot \mathrm{HCl}$ & $74.6 \pm 6.2^{\mathrm{bc}}$ & $211.6 \pm 5.3^{\mathrm{bc}}$ & $0.351 \pm 0.022^{\mathrm{bc}}$ \\
\hline $\mathrm{T}+1.0 \%$ Gly & $62.0 \pm 5.6^{\mathrm{bc}}$ & $193.0 \pm 11.1^{\mathrm{b}}$ & $0.319 \pm 0.011^{\mathrm{b}}$ \\
\hline $\mathrm{T}+2.0 \%$ Gly & $68.8 \pm 4.8^{b c}$ & $196.0 \pm 8.6^{\mathrm{b}}$ & $0.350 \pm 0.012^{\mathrm{bc}}$ \\
\hline $\mathrm{T}+3.0 \%$ Gly & $71.4 \pm 7.3^{\mathrm{bc}}$ & $198.6 \pm 10.4^{\mathrm{b}}$ & $0.357 \pm 0.023^{\mathrm{bc}}$ \\
\hline $\mathrm{T}+4.0 \%$ Gly & $85.6 \pm 6.5^{\mathrm{d}}$ & $213.4 \pm 8.6^{\mathrm{bc}}$ & $0.399 \pm 0.015^{c}$ \\
\hline
\end{tabular}

Values without a common letter indicate a significant difference $(\mathrm{P}<0.05)$. 
weight gain, feed intake and gain:feed ratio of chicks given a $5 \%$ tyrosine diet. The addition of $5 \%$ tyrosine to the basal diet resulted in a significant $(\mathrm{P}<0.05)$ depression in body weight gain, feed intake and gain:feed ratio. The depressed body weight gain, feed intake and gain:feed ratio had a tendency to increase in proportion to the amount of arginine. $\mathrm{HC} 1$ (up to $2.0 \%$ ) and glycine supplemented. Such improvements were statistically significant $(\mathrm{P}<0.05)$ when arginine $\cdot \mathrm{HCl}$ was $2.0 \%$ and glycine $4.0 \%$. Similarly, the addition of 1.5 and $2.0 \%$ arginine $\cdot \mathrm{HCl}$ significantly $(\mathrm{P}<0.05)$ alleviated the depressed feed intake, and the addition of $4.0 \%$ glycine significantly $(\mathrm{P}<0.05)$ improved the gain:feed ratio. Significant $(\mathrm{P}<0.01)$ correlation coefficients $(\mathrm{r}=0.8898$ for arginine supplemented groups and $\mathrm{r}=0.9187$ for glycine supplemented groups) ware ojtained between body weight gain and feed intake.

Table 2. Effect of dietary supplementation of arginine or glycine on nitrogen utilization in chicks given a $5 \%$ tyrosine diet (Mean \pm SEM for 5 birds)

\begin{tabular}{|c|c|c|c|}
\hline \multirow{2}{*}{ Diet } & $\mathrm{N}$ intake & $\mathrm{N}$ retention & \multirow{2}{*}{$\mathrm{N}$ retention rate } \\
\hline & \multicolumn{2}{|c|}{ g/bird/14 days } & \\
\hline Basal (B) & $8.67 \pm 0.27^{\text {ade }}$ & $3.63 \pm 0.16^{\mathrm{a}}$ & $0.419 \pm 0.015^{\mathrm{a}}$ \\
\hline $\mathrm{B}+5.0 \% \mathrm{~L}-\mathrm{Tyr}(\mathrm{T})$ & $6.63 \pm 0.31^{\mathrm{b}}$ & $2.23 \pm 0.15^{\mathrm{bc}}$ & $0.336 \pm 0.013^{\mathrm{b}}$ \\
\hline $\mathrm{T}+0.5 \% \quad \mathrm{~L}-\mathrm{Arg} \cdot \mathrm{HCl}$ & $6.91 \pm 0.28^{\mathrm{bc}}$ & $2.19 \pm 0.13^{\mathrm{bc}}$ & $0.317 \pm 0.015^{\mathrm{bc}}$ \\
\hline $\mathrm{T}+1.0 \% \mathrm{~L}-\mathrm{Arg} \cdot \mathrm{HCl}$ & $7.16 \pm 0.32^{\mathrm{bc}}$ & $2.21 \pm 0.17 \mathrm{bc}$ & $0.307 \pm 0.010^{\mathrm{bcd}}$ \\
\hline $\mathrm{T}+1.5 \% \quad \mathrm{~L}-\mathrm{Arg} \cdot \mathrm{HCl}$ & $8.47 \pm 0.38^{\text {ade }}$ & $2.52 \pm 0.11^{\mathrm{cd}}$ & $0.297 \pm 0.005^{\mathrm{cd}}$ \\
\hline $\mathrm{T}+2.0 \% \mathrm{~L}-\mathrm{Arg} \cdot \mathrm{HCl}$ & $9.12 \pm 0.48^{\mathrm{a}}$ & $2.56 \pm 0.06^{\mathrm{cd}}$ & $0.283 \pm 0.011^{\mathrm{cd}}$ \\
\hline $\mathrm{T}+2.5 \% \mathrm{~L}-\mathrm{Arg} \cdot \mathrm{HCl}$ & $8.46 \pm 0.21^{\text {ade }}$ & $2.30 \pm 0.15^{\mathrm{bc}}$ & $0.271 \pm 0.012^{\mathrm{d}}$ \\
\hline $\mathrm{T}+1.0 \%$ Gly & $7.14 \pm 0.41^{\mathrm{bc}}$ & $2.04 \pm 0.16^{b}$ & $0.285 \pm 0.007^{\mathrm{cd}}$ \\
\hline $\mathrm{T}+2.0 \%$ Gly & $7.64 \pm 0.34^{\mathrm{bcd}}$ & $2.20 \pm 0.10^{\mathrm{bc}}$ & $0.288 \pm 0.005^{\mathrm{cd}}$ \\
\hline $\mathrm{T}+3.0 \%$ Gly & $7.94 \pm 0.42^{\mathrm{cde}}$ & $2.27 \pm 0.20^{\mathrm{bc}}$ & $0.286 \pm 0.021^{\mathrm{cd}}$ \\
\hline $\mathrm{T}+4.0 \%$ Gly & $8.96+0.36^{\mathrm{ae}}$ & $2.76 \pm 0.15^{\mathrm{d}}$ & $0.308 \pm 0.006^{\text {bcd }}$ \\
\hline
\end{tabular}

Values without a common letter indicate a significat difference $(\mathrm{P}<0.05)$.

Table 3. Effect of dietary supplementation of arginine or glycine on the excretion of some nirogenous compounds in excreta of chicks given a $5 \%$ tyrosine diet (Mean $\pm \mathrm{SEM}$ for 5 birds, $\mathrm{mg} /$ bird/4 days)

\begin{tabular}{|c|c|c|c|c|c|c|}
\hline \multirow{2}{*}{$\frac{\text { Diet }}{\operatorname{Basal}(\mathrm{B})}$} & \multirow{2}{*}{$\frac{N \text { intake }}{2884 \pm 170}$} & \multirow{2}{*}{$\frac{N \text { excreted }}{1693 \pm 89}$} & \multicolumn{2}{|c|}{ Uric acid $\mathrm{N}$} & \multicolumn{2}{|c|}{ Total creatinine $\mathrm{N}$} \\
\hline & & & $814 \pm 47 *$ & $(48.3) * *$ & $12.0 \pm 0.6^{* *}$ & $(0.7)^{* *}$ \\
\hline $\mathrm{B}+5.0 \% \mathrm{~L}-\mathrm{Tyr}(\mathrm{T})$ & $2419 \pm 283$ & $1606 \pm 117$ & $640 \pm 37$ & $(41.0)$ & $27.7 \pm 2.1$ & $(1.7)$ \\
\hline $\mathrm{T}+0.5 \% \quad \mathrm{~L}-\mathrm{Arg} \cdot \mathrm{HCl}$ & $2227 \pm 100$ & $1608 \pm 50$ & $705 \pm 23$ & $(44.1)$ & $27.1 \pm 2.3$ & $(1.7)$ \\
\hline $\mathrm{T}+1.0 \% \mathrm{~L}-\mathrm{Arg} \cdot \mathrm{HCl}$ & $2205 \pm 184$ & $1786 \pm 132$ & $806 \pm 29 *$ & $(46.1)$ & $26.8 \pm 2.0$ & $(1.5)$ \\
\hline $\mathrm{T}+1.5 \% \mathrm{~L}-\mathrm{Arg} \cdot \mathrm{HCl}$ & $2694 \pm 165$ & $1977 \pm 150$ & $900 \pm 62 * *$ & $(45.6)$ & $24.2 \pm 1.5$ & $(1.2)^{* *}$ \\
\hline $\mathrm{T}+2.0 \% \mathrm{~L}-\mathrm{Arg} \cdot \mathrm{HCl}$ & $3080 \pm 272$ & $2127 \pm 115$ & $993 \pm 54^{* *}$ & $(47.0) *$ & $23.8 \pm 1.3$ & $(1.1)^{* *}$ \\
\hline $\mathrm{T}+2.5 \% \mathrm{~L}-\mathrm{Arg} \cdot \mathrm{HCl}$ & $2824 \pm 117$ & $2124 \pm 115$ & $973 \pm 39 * *$ & $(44.8)$ & $24.0 \pm 2.9$ & $(1.1) * *$ \\
\hline $\mathrm{T}+1.0 \%$ Gly & $2311 \pm 149$ & $1690 \pm 65$ & $823 \pm 23^{* *}$ & $(50.8) * *$ & $27.0 \pm 1.3$ & $(1.6)$ \\
\hline $\mathrm{T}+2.0 \%$ Gly & $2551 \pm 110$ & $1759 \pm 37$ & $833 \pm 34 * *$ & $(47.6) *$ & $30.3 \pm 1.8$ & $(1.6)$ \\
\hline $\mathrm{T}+3.0 \%$ Gly & $2760 \pm 158$ & $2016 \pm 89$ & $1035 \pm 48^{* *}$ & $(51.4) * *$ & $33.9 \pm 3.7$ & (1.7) \\
\hline $\mathrm{T}+4.0 \%$ Gly & $3032 \pm 216$ & $2068 \pm 95$ & $1202 \pm 68 * *$ & $(58.1) * *$ & $34.0 \pm 1.8$ & $(1.7)$ \\
\hline
\end{tabular}

Values with asterisk are significantly different from $\mathrm{T}$ group: ** $\mathrm{P}<0.01, * \mathrm{P}<0.05$. Numbers in parentheses represent means expressed as a percentage of $\mathrm{N}$ excreted. 
Table 2 gives the effect of dietary supplementation of arginine or glycine on nitrogen utilization in chicks given a $5 \%$ tyrosine diet. The adfition of excess tyrosine resulted in a significant $(\mathrm{P}<0.05)$ depression in nitrogen retention rate. The addition of $2.0 \%$ arginine. $\mathrm{HCl}$ or $4.0 \%$ glycine to the tyrosine excess diet caused a significant $(\mathrm{P}<0.05)$ increase in nitrogen intake and the supplementation of $4.0 \%$ glycine resulted in a significant $(\mathrm{P}<0.05)$ increase in nitrogen retention. A significant $(\mathrm{P}<0.05)$ decrease in nitrogen retention rate was obtained when $1.5,2.0$ and $2.5 \%$ of arginine $\cdot \mathrm{HCl}$ or $1.0,2.0$ and $3.0 \%$ of glycine were supplemented.

Table 3 shows the effect of dietary supplementation of arginine or glycine on the excretion of some nitrogenous compounds in excreta of chicks given a $5 \%$ tyrosine diet. Feeding the excess tyrosine diet resulted in a significant $(\mathrm{P}<0.05)$ decrease in the excretion of uric acid nitrogen, while the excretion of total creatinine, to a lesser extent, increased significantly $(\mathrm{P}<0.01)$. The addition of arginine or glycine counteracted the depression of the proportion of uric acid in nitrogen of excreta that had been caused by giving excessive amounts of tyrosine.

Table 4 shows the effect of dietary supplementation of arginine or glycine on free amino acid concentrations in plasma of chicks given a $5 \%$ tyrosine diet. The plasma concentrations of arginine and threonine were reduced in chicks given excess tyrosine. In contrast, there was a highly significant increase in tyrosine concentration, which was elevated about 30 -fold. When $2.0 \%$ arginine $\cdot \mathrm{HCl}$ or $4.0 \%$ glycine was included into the tyrosine excess diet, the plasma tyrosine concentration was moderately reduced. The concentration of plasma phenylalanine also underwent a change similar to that of the plasma tyrosine.

The appearance of external foot lesions ${ }^{4}$ was observed in chicks given a tyrosine excess diet in two out of five chicks. In chicks that received a tyrosine excess diet containing $1.5,2.0 \%$ arginine $\cdot \mathrm{HCl}$ or $4.0 \%$ glycine, external foot lesions were not observed. There was not, however, a close relationship between the supplementation of arginine or glycine and the occurrence of signs of tyrosine toxicity.

Table 4. Effect of dietary supplementation of arginine or glycine on free amino acid concentrations in plasma of chicks given a $5 \%$ tyrosine diets ${ }^{1}$

\begin{tabular}{|c|c|c|c|c|c|c|c|c|c|c|c|}
\hline \multirow{2}{*}{ Diet } & \multirow{2}{*}{$\underset{\text { acid }}{\text { Amino }}$} & Lys & Arg & Thr & Gly & Val & Met & Ile & Leu & Tyr & Phe \\
\hline & & \multicolumn{10}{|c|}{$\mu \mathrm{mol} / 100 \mathrm{~m} l$ plasma } \\
\hline $\operatorname{Basal}(\mathrm{B})$ & & 105 & 34 & 120 & 75 & 32 & 9 & 22 & 25 & 21 & 18 \\
\hline $\mathrm{B}+5.0 \%$ & $\mathrm{~L}-\mathrm{Tyr}(\mathrm{T})$ & 95 & 16 & 74 & 66 & 40 & 6 & 24 & 24 & 634 & 61 \\
\hline $\mathrm{T}+0.5 \%$ & $\mathrm{~L}-\mathrm{Arg} \cdot \mathrm{HCl}$ & 132 & 18 & 54 & 52 & 19 & 8 & 16 & 18 & 519 & 47 \\
\hline $\mathrm{T}+1.0 \%$ & $\mathrm{~L}-\mathrm{Arg} \cdot \mathrm{HCl}$ & 99 & 35 & 51 & 68 & 38 & 10 & 27 & 26 & 633 & 82 \\
\hline $\mathrm{T}+1.5 \%$ & $\mathrm{~L}-\mathrm{Arg} \cdot \mathrm{HCl}$ & 125 & 43 & 66 & 72 & 40 & 10 & 26 & 27 & 629 & 82 \\
\hline $\mathrm{T}+2.0 \%$ & $\mathrm{~L}-\mathrm{Arg} \cdot \mathrm{HCl}$ & 123 & 41 & 51 & 64 & 36 & 5 & 19 & 24 & 442 & 38 \\
\hline $\mathrm{T}+2.5 \%$ & $\mathrm{~L}-\mathrm{Arg} \cdot \mathrm{HCl}$ & 152 & 64 & 79 & 87 & 48 & 8 & 29 & 32 & 673 & 63 \\
\hline $\mathrm{T}+1.0 \%$ & Gly & 110 & 32 & 66 & 155 & 47 & 9 & 33 & 34 & 696 & 89 \\
\hline $\mathrm{T}+2.0 \%$ & Gly & 94 & 34 & 73 & 189 & 38 & 11 & 27 & 27 & 627 & 54 \\
\hline $\mathrm{T}+3.0 \%$ & Gly & 109 & 38 & 77 & 250 & 45 & 13 & 34 & 28 & 589 & 67 \\
\hline $\mathrm{T}+4.0 \%$ & Gly & 77 & 23 & 70 & 286 & 29 & 10 & 22 & 22 & 375 & 46 \\
\hline
\end{tabular}

1. Samples were pooled from 5 chicks/group. 


\section{Discussion}

The beneficial effect of the limiting amino acid for the growth of young rats against the tyrosine toxicity has been reported ${ }^{16)}$. In the present experiment, nitrogen retention rate was not improved by the supplementation of arginine or glycine and which suggested that the ameliorative effect of arginine or glycine was done in some way(s) unrelated to its role as the limiting amino acid. The evidence indicated that the improvement of the depressed body weight gain in the arginine supplemented groups primarily depends on the increment in feed intake, while in the glycine supplemented groups, on the improvement of gain: feed ratio. A difference of the effect on chick's performance between arginine and glycine supplementation may reflect the different metabolic function of both amino acids. It is conceivable that the recovery of the depressed feed intake, which resulted in the improvement of growth depression, augmented the resistance of chicks to excess tyrosine, because a close correlation between body weight gain and feed intake was observed.

It has been shown that feeding chicks a diet containing an excessive amount of tyrosine increased the chick's requirement for arginine ${ }^{6,7)}$. Austic and NESHEIM ${ }^{7)}$ showed that a tyrosine excess diet augmented arginine requirement of chicks by enhancing the kidney arginase activity. Glycine is one of the substrates for uric acid biosynthesis ${ }^{17)}$ and supplemental glycine might function in alleviation of the tyrosine toxicity by enhancing the excretion of nitrogen through the uric acid formation. The observation that the addition of glycine largely increased the proportion of uric acid in total nitrogen of excreta might support this hypothesis. The other reason why supplemental arginine or glycine was effective to alleviate the adverse effect of chicks given a tyrosine excess diet might relate to the increased creatinine excretion. The domestic fowl excretes aromatic compounds as ornithuric acid, which is conjugated aromatic compounds with ornithine ${ }^{18)}$. The required ornithine could be supplied through the reaction forming urea and the transamidination reaction forming creatine ${ }^{17}$. One could, therefore, postulate that unabsorbed tyrosine was degraded by the intestinal bacteria and then excreted as ornithuric acid ${ }^{5)}$. BAKKE ${ }^{19)}$ identified various simple phenols in the urine of rats given a $10 \%$ tyrosine diet and suggested that production of these compounds may contribute to the manifestation of tyrosine toxicity.

In the present experiment, plasma tyrosine concentration of chicks given a $5 \%$ tyrosine diet supplemented with $4.0 \%$ glycine decreased to about $60 \%$ of plasma tyrosine of chicks given a $5 \%$ tyrosine diet alone. Alam et al. ${ }^{20)}$ reported that dietary addition of glycine to a diet containing excess tyrosine caused an increase in tyrosine aminotransferase activity and which accompanied by a substantial decrease in plasma tyrosine concentration. Further investigation will be required to clarify the relationship between dietary glycine and tyrosine aminotransferase activity in chicks under circumstance of excess tyrosine.

\section{Acknowledgment}

We wish to thank Dr. D. N. SALTER for his critical reading of the manuscript.

\section{Summary}

Experiment was done to determine whether arginine or glycine was required to improve 
the adverse effect of a tyrosine excess diet. Chicks given the tyrosine excess diet demonstrated the retarded growth, depressed feed intake and decreased gain:feed ratio. These indices had a tendency to increase with the level of arginine $\cdot \mathrm{HCl}$ (up to $2.0 \%$ ) or glycine supplementation. The addition of 1.5 and $2.0 \%$ arginine $\cdot \mathrm{HCl}$ to the tyrosine excess diet significantly $(\mathrm{P}<0.05)$ increased the feed intake and the addition of $4.0 \%$ glycine significantly $(\mathrm{P}<0.05)$ improved the gain:feed ratio. The decreased nitrogen retention rate, which was caused by feeding the tyrosine excess diet, was not improved by the supplementation of arginine or glycine. Chicks given the tyrosine excess diet significantly $(P<0.01)$ increased the excretion of total creatinine. Supplemental arginine or glycine did not result in a substantial change in the increased excretion of total creatinine. The free tyrosine concentration in plasma was remarkably elevated by feeding excess tyrosine. When $2.0 \%$ arginine $\cdot \mathrm{HCl}$ or $4.0 \%$ glycine was added to the tyrosine excess diet, plasma tyrosine concentration was slightly lower than that of chicks given the tyrosine excess diet. The results showed that the beneficial effect of supplemental arginine or glycine on the growth depression due to excess tyrosine could be attributed to the significant improvement of feed intake or gain:feed ratio.

\section{References}

1) Harper, A. E., N. J. Benevenga and R. M. Wohlheuter: Physiol. Rev., 55, 428, 1970.

2) SAnford, P.E., A. J. Wei and R.E. ClegG: Poult. Sci., 33, 585, 1954.

3) Okumura, J. and K. Yamaguchi: Japan. Poult. Sci., 17, 135, 1980.

4) Okumura, J., K. Yamaguchi and M. Yanaka: Japan. Poult. Sci., 17, 256, 1980.

5) Nesheim, M.C. and J.D. Garlich: J. Nutr., 79, 311, 1963.

6) Sмiтн, R. E.: J. Nutr., 95, 547, 1968.

7) Austic, R. E. and M. C. Nesheim: J. Nutr., 100, 855, 1970.

8) Snetsinger, D. C. and H. M. Scott: Poult. Sci., 40, 1675, 1961.

9) Okumura, J., H. Tanaka and T. Muramatsu: Japan. Poult. Sci., 15, 163, 1978.

10) Nesheim, M.C., J. D. Garlich and D. T. Hopkins: J. Nutr., 78, 89, 1962.

11) National Research Council: Nutrient Requirements of Poultry, 7th revised ed. National Academy of Sciences, Washington D. C., U.S. A., 1977.

12) Pudelkiewicz, W. J., M.W. Stutz and L. D. Matterson: Poult. Sci., 47, 1274, 1968.

13) Hawk, P.B., B.L. Oser and W.H. Summerson: Practical Physiological Chemistry, 13th ed. McGraw-Hill Book Co., New York, U.S. A., 1954.

14) Okumura, J. and S. Mori: Br. Poult. Sci., 20, 421, 1979.

15) Duncan, D.B.: Biometrics, 11, 1, 1955.

16) Muramatsu, K., T. Arito and H. Tsuda: J. Nutr. Sci. Vitaminol., 22, 397, 1976.

17) Harper, H. A.: Review of Physiological Chemistry, 16th ed. Maruzen Co., Tokyo, Japan, 1978.

18) Williams, R. T.: Fed. Proc., Fed. Am. Soc. Ekp. Biol., 26, 1029, 1967.

19) BАKKE, O. M.: J. Nutr., 98, 217, 1969.

20) Alam, S. Q., A. M. Boctor, Q. R. Rogers and A.E. Harper: J. Nutr., 93, 317, 1967. 


\title{
ニワトリヒナにおけるチロシン過剩障害におよぼす アルギニンあるいはグリシン添加の影響
}

\author{
谷 中 正 男 - 奥 村 純 市 \\ 名古屋大学農学部, 名古屋市 $\bar{T} 464$
}

単一アミノ酸を過剩に含む飼料をニワトリヒナに給与 すると，成長の抑制や飼料摂取量の減少がみられ，これ らの害作用はアルギニンやグリシンの添加によって緩和 されることが知られている。本実験では，チロシン過剩 飼料給与によって生じた成長抑制におよぼすアルギニン あるいはグリシンの緩和効果について, 増体量, 飼料椇 取量, 飼料効率, 血漿遊離アミノ酸濃度および窒素の利 用性などを指標として研究した。

試験飼料は，蛋白質源としてレーメチオニンを補足した 大豆蛋白質を用いて基礎飼料 $(20 \% \mathrm{CP})$ を調製し，こ れに $5 \%$ のLーチロシンを添加してチロシン過剩飼料とし た。さらにチロシン過剩飼料に $0.5,1.0,1.5,2.0$ およ び $2.5 \%$ の-アルギニン塩酸塩 (以下アルギニンと略す) を，また，1.0，2.0，3.0および $4.0 \%$ のグリシンをそ れぞれ添加してアルギニン添加飼料およびグリシン添加 飼料を調製した。供試ヒナは 8 日齢の白色レグホーン種 雄を用い, 14 日間試験飼料および水を自由掑取させた。

チロシン 過剩飼料をヒナに 給与すると基礎飼料に比 べ, 増体量, 飼料摂取量および飼料効率が著しく減少し た。これらの諸項目は, 添加したアルギニン $(2.0 \%$ ま で）あるいはグリシンの増加に比例して増加する傾向が みられた。増体量は $2.0 \%$ のアルギニンおよび $4.0 \%$ の
グリシンの添加によって, 飼料摂取量は 1.5 および $2.0 \%$ のアルギニンの添加によって, 飼料効率は $4.0 \%$ のグリ シンの添加によって有意な改善がみられた $(\mathrm{P}<0.05)$ 。 窒素蓄積率 (窒素蓄積量/窒素掑取星) は, チロシン過剩 飼料給与により著しい隇少がみられ，これはアルギニン あるいはグリシンの添加によって改善されなかった。チ ロシン過剩飼料の摂取は, 尿酸態窒素排泄量の減少をも たらしたが，一方総クレアチニン態窒素の排泄量を增加 させた。アルギニンあるいはグリシンの添加により尿酸 態窒素排泄量洼基礎飼料の排泄量より増加したが, 総ク レアチニン態窒素排泄量に変化はみられなかった。血漿 遊離チロシン濃度は, チロシン過剩飼料給与によって著 しく增加したが, アルギニンあるいはグリシンの添加に よって幾分減少の傾向がみられた。また血漿遊離フェニ ルアラニン濃度は, 遊離チロシン濃度の变化と同様の傾 向を示した。

これらの結果から,チロシン過剩飼料給与によって生 じた成長抑制汇対するフルギニンあるいはグリシンの緩 和効果汢窒素蓄積率の改善によるのではなく, 飼料摄取 量の增加あるいは飼料効率の改善によることが示され た。

（家禽会誌，18，151～157, 1981） 